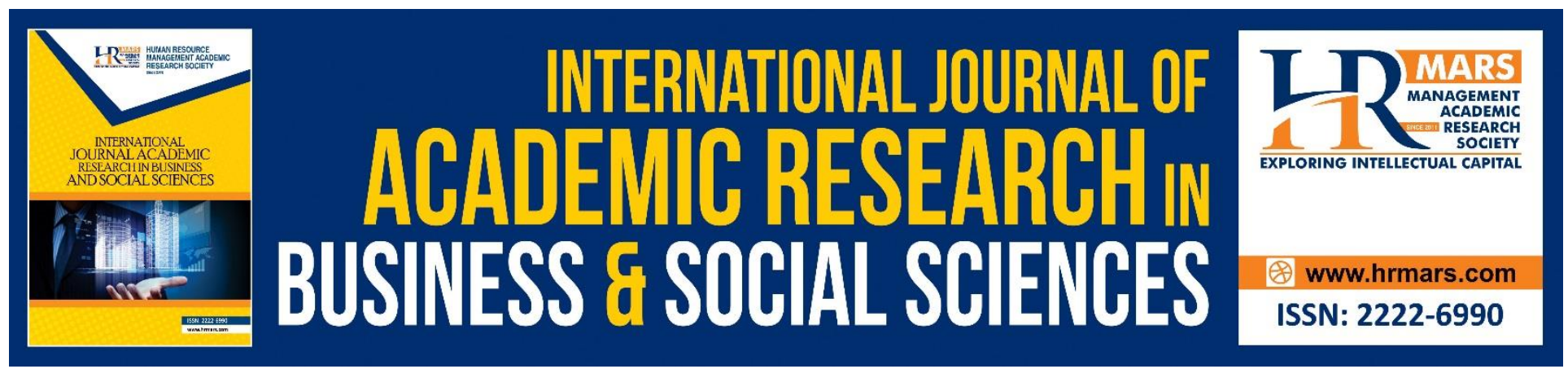

\title{
Implementation of Targhib and Tarhib Method In the M- Prayer Robot Module
}

Siti Fauziah Mohd Amin, Sabariah Sharif, Mad Nor Madjapuni, Muralindran Mariappan

To Link this Article: http://dx.doi.org/10.6007/IJARBSS/v10-i7/7609

DOI:10.6007/IJARBSS/v10-i7/7609

Received: 21 May 2020, Revised: 24 June 2020, Accepted: 10 July 2020

Published Online: 25 July 2020

In-Text Citation: (Amin et al., 2020)

To Cite this Article: Amin, S. F. M., Sharif, S., Madjapuni, M. N., \& Mariappan, M. (2020). Implementation of Targhib and Tarhib Method In the M-Prayer Robot Module. International Journal of Academic Research in

Business and Social Sciences, 10(7), 797-807.

Copyright: (c) 2020 The Author(s)

Published by Human Resource Management Academic Research Society (www.hrmars.com)

This article is published under the Creative Commons Attribution (CC BY 4.0) license. Anyone may reproduce, distribute, translate and create derivative works of this article (for both commercial and non-commercial purposes), subject to full attribution to the original publication and authors. The full terms of this license may be seen

at: http://creativecommons.org/licences/by/4.0/legalcode

Vol. 10, No. 7, 2020, Pg. 797 - 807

http://hrmars.com/index.php/pages/detail/IJARBSS

JOURNAL HOMEPAGE

Full Terms \& Conditions of access and use can be found at http://hrmars.com/index.php/pages/detail/publication-ethics 


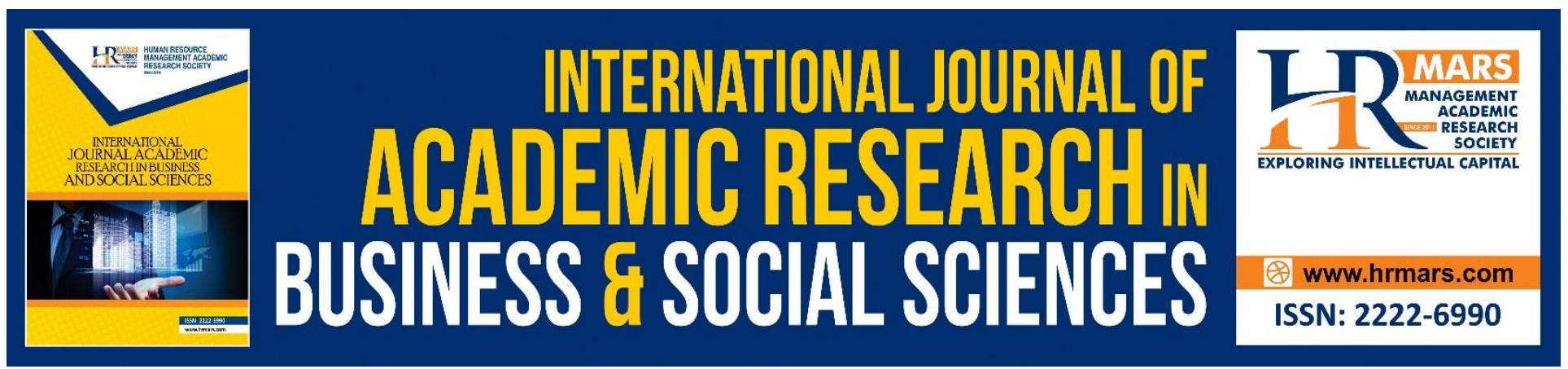

\title{
Implementation of Targhib and Tarhib Method In the M-Prayer Robot Module
}

\author{
Siti Fauziah Mohd Amin ${ }^{1}$, Sabariah Sharif², Mad Nor Madjapuni ${ }^{3}$, \\ Muralindran Mariappan ${ }^{1}$ \\ Faculty of Psychology and Education ${ }^{1-3}$, Faculty of Engineering ${ }^{4}$, Universiti of Malaysia Sabah, \\ 88400, Kota Kinabalu, Sabah, Malaysia
}

\begin{abstract}
The targhib and tarhib method are methods derived from the al-Quran al-Karim. These methods, which are synonymous with the field of preaching, are also relevant for application in the education domain. Implementation of targhib and tarhib method in learning and facilitating (PdPc) of fard prayers are per Quranic texts and hadiths related to fard prayers itself. Accordingly, the objectives of this research were to identify the use of targhib and tarhib in the education field and propose its implementation in the M-Prayer Robot module. This study was a qualitative research using document analysis method. The search for scientific materials such as journal articles, conference papers, theses in digital and non-digital forms was done utilising the keywords "targhib method", tarhib method", "targhib", "tarhib". The findings revealed that the implementation of targhib and tarhib methods could be diversified according to the suitability of the activities contained in the M-Prayer Robot Module to make learning and facilitation (PdPc) of fard prayers more efficient in improving fard prayer theory and practice.
\end{abstract}

Keywords: Targhib Method, Tarhib Method, Targhib, Tarhib, Module.

\section{Introduction}

The words targhib and tarhib are derived from Arabic. Targhib is derived from the word "raghaba" which means to give something that is liked. Tarhib is derived from the word "rahhaba" which means to scare someone. The targhib method is used to convey good news, rewards and paradises while the tarhib method is used to explain the torture, evil, punishment, sin and hell (Hussin, 2005). The application of targhib and tarhib method is derived from the Quran and hadith. Prophet Muhammad (PBUH) adopted this method in delivering preach, conveying Islamic teachings, teaching worship and educating Muslims in all regards of life (Ariyani \& Nursalin, 2018). Among the applications of the targhib method are related to fard prayers in the Qur'an and the hadith (al-Munziri, 1987) which said: 
INTERNATIONAL JOURNAL OF ACADEMIC RESEARCH IN BUSINESS AND SOCIAL SCIENCES

Vol. 10, No. 7, July, 2020, E-ISSN: 2222-6990 @ 2020 HRMARS

Allah said:

"And establish prayer at the two ends of the day and at the approach of the night. Indeed, good deeds do away with misdeeds. That is a reminder for those who remember."

(Surah Hud :114)

The meaning of the hadith:

From Abu Hurairah RA, he said, I heard the Prophet Muhammad (PBUH) said, "If there was a river at the door of anyone of you and he took a bath in it five times a day would you notice any dirt on him?" They said, "Not a trace of dirt would be left." Prophet Muhammad (PBUH) added:

"That is the example of the five prayers with which Allah blots out (annuls) evil deeds."

(al-Bukhari and Muslim)

Whereas the use of tarhib method in the Quran is related to fard prayers: -

Allah said:

\author{
"What put you into Saqar?" \\ They will say, "We were not of those who prayed."
}

(Surah al-Muddathir: 42-43)

The application of targhib and tarhib methods related to fard prayers in the Quran promises good rewards for those who complete fard prayers and punishment for those who neglect fard prayers (al-Munziri, 1987). In today's educational system, this method can be spread to use in fard prayers prayer education, either informally in mosques or surau or formally in teaching and facilitating fard prayers in schools. Although generally accepted, the learning and facilitation (PdPc) of fard prayers is more synonymous with alternative approaches and prototypes (Salleh, 2011). Still, the combination of both techniques with the targhib and tarhib system can make learning and facilitation ( $\mathrm{PdPc}$ ) of fard prayer more potent in boosting students' motivation and interest in intensifying knowledge of the principles and practice of fard prayers. The nature of human always demands encouragement, inspiration, motivation, rebuke, warning and advice in accomplishing something in life per the use of targhib and tarhib method (Ismawati, 2018; Hussin, 2005).

The use of targhib and tarhib methods in the teaching and facilitation (PdPc) of fard prayers is not confined to the employment of Quranic verses that are related to reward and fard prayers in ukhrawi (related to the afterlife) form. In fact, this method can be translated into various types of targhib and tarhib that are practised in the educational world. The Prophet Muhammad (PBUH) applied this system by exercising his technique of giving guidance, motivation, reward or award to his companions. He followed the targhib and tarhib method with a ukhrawi-like reward that will be received in the hereafter as well as a worldly response by giving praise when a friend does good and punishes when a friend does something that violates Islamic law (Ariyani \& Nursalin, 2018). It is evident through the following hadith:

From Muhammad Ibn Katsir, from Sufyan, from al-Masy, from Ibrahim, from the Alqamah said:

We were in Him, then Ibn Mas'ud read Yusuf's letter,

Then a man asks: is that so when it comes down?

Ibn Mas'ud replied: I read before the Prophet Muhammad (PBUH) and he said:

"Praise be to you." Then smelled Khamr from his mouth, 
INTERNATIONAL JOURNAL OF ACADEMIC RESEARCH IN BUSINESS AND SOCIAL SCIENCES Vol. 10, No. 7, July, 2020, E-ISSN: 2222-6990 @ 2020 HRMARS

\section{then he said: Do you unite the Book of Allah by drinking the khamr?}

Then the had sentence was imposed on him. "

(al-Bukhari and Muslim)

According to Jasmi and Tamuri, method of targhib and tarhib is fit and useful in education. Nevertheless, the Prophet Muhammad (PBUH) encouraged the use of targhib method rather than tarhib method in communicating knowledge. The use of targhib method creates excitement while the use of tarhib method provokes fear (Jasmi \& Tamuri, 2013). The student-centred approach makes students more interested in actively engaging in learning and facilitation activities (PdPc). The encouragement, inspiration, good news and rewards provided by the teacher enhances the motivation and desire of the student to gain experience. However, for students who are more stringent and indifferent, the use of the tarhib method raises awareness and understanding so that students concentrate more on the pursuit of knowledge as well as mahmudah (good deeds) throughout learning and facilitation process (PdPc) (Ma'rufin, 2015).

\section{Research Objectives}

The research concentrated on the targhib and tarhib method set out two research objectives as follows:

1. Identify the implementation of targhib and tarhib method in education.

2. Propose implementation of targhib and tarhib method in M-Prayer Robot Module.

\section{Research Methodology}

This investigation is qualitative research employing document analysis methods from written materials related to targhib and tarhib methods from reference books, articles and theses to gather information on the management of targhib and tarhib methods in the education environment. This knowledge is then translated into appropriate practical techniques applied in 21st-century education by concentrating on student-centred learning strategies to promote active student engagement in learning and facilitation of fard prayer utilising the M-Prayer Robot Module.

\section{Findings}

The research results discussion splits into two sections in line with the objectives of the investigation. The first discussion is on the implementation of targhib and tarhib methods in education and the second discussion is on the implementation of targhib and tarhib methods in the M-Prayer Robot Module:

\section{Implementation of The Targhib and Tarhib Method in The Field of Education}

Targhib method revolves around reward, encouragement, appreciation or award rendered to students who manifest progressive engagement and outstanding accomplishments in learning and facilitation (Anggraini, 2018). This task intends to serve as an incentive and motivation for students to achieve their learning objectives and facilitation (Prahara, 2015). There are multiple methods of teaching that teachers can exercise during learning and facilitation (PdPc) (Ariyani \& Nursalin, 2018):

1. Giving respect in the form of words or gestures. Words like good, excellent, smart, Mumtaz and the like and gestures like nodding and applause.

2. Granting reward in the form of materials such as stationery or food. 
INTERNATIONAL JOURNAL OF ACADEMIC RESEARCH IN BUSINESS AND SOCIAL SCIENCES Vol. 10, No. 7, July, 2020, E-ISSN: 2222-6990 @ 2020 HRMARS

3. Praising in front of his or her classmates, schoolmates or parents.

The management of targhib method should be followed by the faith and spiritual value of the students. Teachers need to emphasise the significance of mastering the knowledge to students, especially fardu ain (personally obligatory) and fardu kifayah (communally obligatory). This method is not confined to academic achievement solely but should be extended by awarding students a targhib for those who present transcendent character and righteousness throughout learning and facilitation (PdPc). Nonetheless, targhib should be performed with due consideration to prevent it from perceived as a wage. Educators need to make relevant assessments based on the needs depending on the school atmosphere and the personality of the student (Ma'rufin, 2015). Executing targhib method not only intensifies the student spirit who earns respect, reward and praise but can also inspire and encourage others (Ariyani \& Nursalin, 2018).

While for the tarhib method, it concerns giving punishment, advice, criticism, threats and warning to students who need it. Pupils who exhibit a passive association in learning and facilitation, constantly find excuses to complete assigned tasks and make disciplinary mistakes during learning and facilitation means should be taught using the tarhib method (Ma'rufin, 2015). The teacher needs to find out the precise information and try to find the constituents that are causing the symptoms and choosing the appropriate form of the pupil's condition. The process of teaching should be based on love and reasonable consideration aimed at raising awareness and understanding of the student and should be accompanied by hope, forgiveness and trust from the teacher. Among the forms of tarhib method performed by the Prophet Muhammad (PBUH) who said (Ariyani \& Nursalin, 2018):

1. Indicates an error with a signal.

2. Shows mistakes in the form of warnings, rebuke, threats and firm reminders.

3. Gives punishment by giving tasks.

4. Gives physical punishment that does not harm.

\section{Implementation of the Targhib and Tarhib Method in the M-Prayer Robot Module}

Discussions on the implementation of the targhib and tarhib methods in M-Prayer Robot Module are divided into submodules and activities contained in the module. The subdivision is based on the Imam al-Ghazali Islamic Education curriculum model (Darussalam, 2018) and the Curriculum and Assessment Standard Document (DSKP) Form One Islamic education (KPM, 2015).

\section{a) Ta'aruf, Targhib, and Fard Prayers Submodule}

The fard prayer $t a^{\prime}$ aruf submodule focuses on the introduction of fard prayers. It covers the meaning, history, mandatory conditions and valid conditions of performing fard prayers. In the submodule of targhib prayer, it discusses the wisdom of performing fard prayers according to Islam and its advantages according to science. Besides, the submodule of the fard prayer of tarhib addresses the effect and the punishment neglecting the fard prayer. 
INTERNATIONAL JOURNAL OF ACADEMIC RESEARCH IN BUSINESS AND SOCIAL SCIENCES

Vol. 10, No. 7, July, 2020, E-ISSN: 2222-6990 (C) 2020 HRMARS

Table 1: Implementation of Targhib and Tarhib Method in

Fard Prayers' Ta'aruf, Targhib and Tarhib Submodule

\begin{tabular}{|c|c|c|}
\hline Activities & Implementation of the Targhib Method & Implementation of the Tarhib Method \\
\hline $\begin{array}{l}\text { Ta'aruf } \\
\text { Fard } \\
\text { Prayer }\end{array}$ & $\begin{array}{l}\text { The "star" is given to the student who } \\
\text { successfully places mandatory conditions } \\
\text { fard prayers card and valid conditions fard } \\
\text { prayers card on the mind map (treemap). }\end{array}$ & $\begin{array}{l}\text { The issuance of penalty cards for } \\
\text { students who do not complete the task to } \\
\text { prepare a mind map on the meaning, } \\
\text { prove, mandatory conditions and } \\
\text { stringent conditions of prayer for } \\
\text { reinforcement. }\end{array}$ \\
\hline $\begin{array}{l}\text { Targhib } \\
\text { Fard } \\
\text { Prayer I }\end{array}$ & $\begin{array}{l}\text { The "star" is given to the students who } \\
\text { can respond appropriately during a } \\
\text { revision session. } \\
\text { The M-Prayer Robot Module recites } \\
\text { Quranic verses and hadiths regarding the } \\
\text { reward and wisdom of establishing fard } \\
\text { prayers. }\end{array}$ & $\begin{array}{l}\text { The issuance of penalty cards for } \\
\text { students who do not complete the task } \\
\text { related to the wisdom of fard prayer } \\
\text { completion. }\end{array}$ \\
\hline $\begin{array}{l}\text { Targhib } \\
\text { Fard } \\
\text { Prayer } \\
\quad \text { II }\end{array}$ & $\begin{array}{l}\text { The "star" is given to the students who } \\
\text { can respond appropriately during a } \\
\text { revision session. } \\
\text { The gift card is given to the group that } \\
\text { produces the best group work on the } \\
\text { benefits of fard prayer based on science. }\end{array}$ & $\begin{array}{l}\text { The assignment of tasks to the } \\
\text { unsuccessful group who fail to present } \\
\text { the benefits of fard prayer based on } \\
\text { science. }\end{array}$ \\
\hline $\begin{array}{l}\text { Tarhib } \\
\text { Fard } \\
\text { Prayer }\end{array}$ & $\begin{array}{l}\text { The "star" is given to the students who } \\
\text { can respond appropriately during a } \\
\text { revision session and to the student } \\
\text { producing a neatly rendered fard prayer } \\
\text { mizan. }\end{array}$ & $\begin{array}{l}\text { The M-Prayer Robot Module recites } \\
\text { Quranic verses regarding the person } \\
\text { neglecting the fard prayers. } \\
\text { Fill in the form of benefits of fard prayers. } \\
\text { Students recite istighfar and prayer of } \\
\text { repentance. }\end{array}$ \\
\hline \multicolumn{3}{|c|}{$\begin{array}{l}\text { b) Rules of Fard Prayers Submodule } \\
\text { The rules submodules are the ones that discuss the principles of fard prayers, namely the qalbi (heart), } \\
\text { the qauli (word) and the fikli (deeds) of the theoretical and practical aspects. }\end{array}$} \\
\hline
\end{tabular}




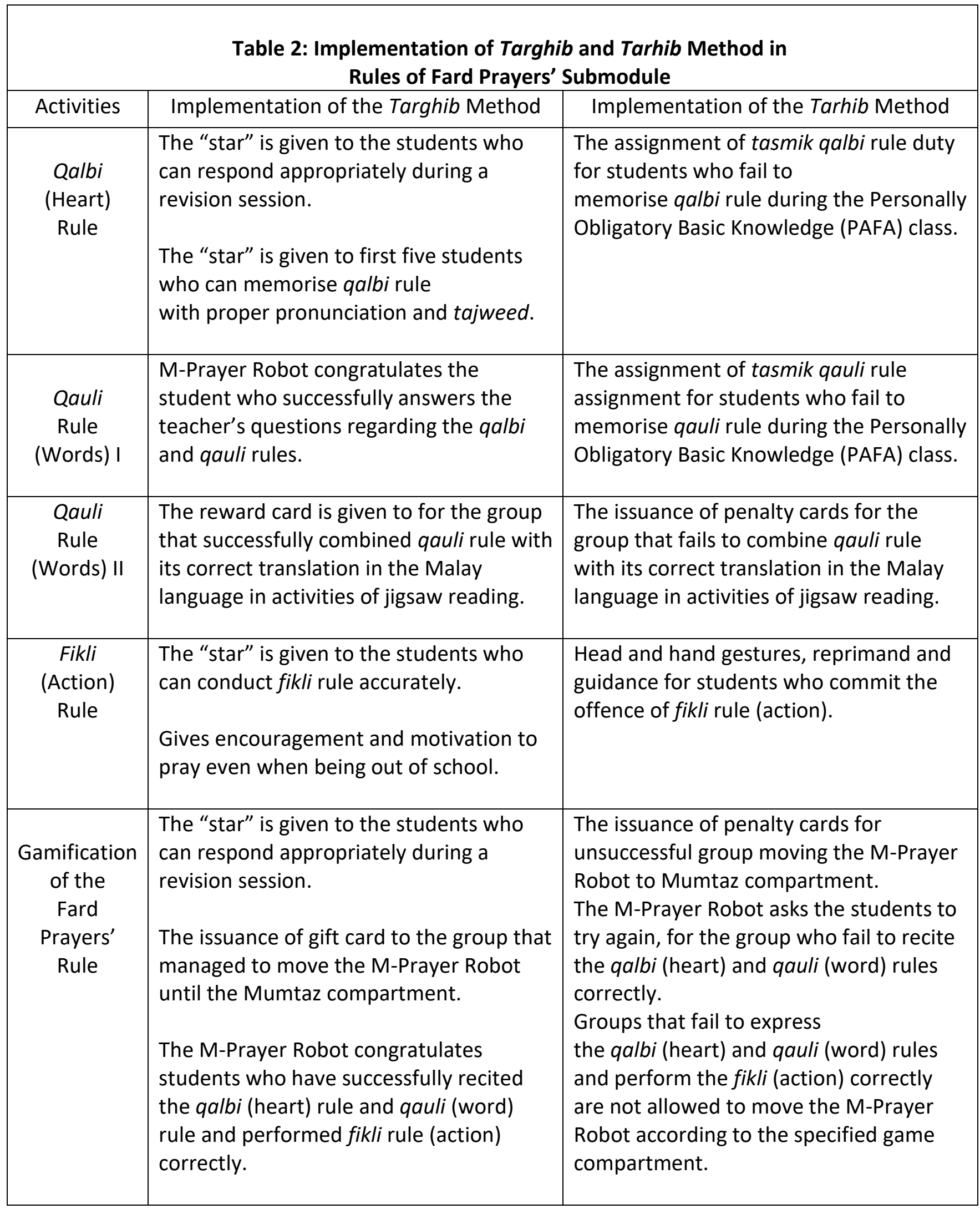




\begin{tabular}{|l|l|l|}
\hline $\begin{array}{l}\text { Permission to move the M-Prayer Robot } \\
\text { to the next compartment for the group } \\
\text { that successfully recited the qalbi (heart) } \\
\text { and qauli (word) rules and performed } \\
\text { the fikli (action) rule pillar precisely } \\
\text { according to the specified game } \\
\text { compartment. }\end{array}$ & \\
\end{tabular}

\section{c) Sunnah acts of Fard Prayers Submodule}

The sunnah acts of fard prayers submodule focus on the practice of ab'ad and hai'ah in a theoretical and practical way from the aspects of qauli (words) and fikli (action):

Table 3: Implementation of the Targhib and Tarhib Method in the Sunnah acts of Fard Prayers' Submodules

\begin{tabular}{|c|c|c|}
\hline Activities & Implementation of the Targhib Method & Implementation of the Tarhib Method \\
\hline $\begin{array}{l}\text { Sunnah acts } \\
\qquad A b^{\prime} \text { ad I }\end{array}$ & $\begin{array}{l}\text { The "star" is given to the students who } \\
\text { can respond appropriately during a } \\
\text { revision session. } \\
\text { Increase the enthusiasm and motivation } \\
\text { of the students to repeat the expression } \\
\text { of ab'ad, especially for students who } \\
\text { have not yet mastered final tahiyat (final } \\
\text { recital in prayer) and qunut prayers. }\end{array}$ & $\begin{array}{l}\text { Multiple foam map assignments to } \\
\text { students who are unable to distinguish } \\
\text { between sunnah acts } a b^{\prime} a d \text { and sunnah } \\
\text { acts hai'ah. }\end{array}$ \\
\hline $\begin{array}{l}\text { Sunnah acts } \\
\qquad A b^{\prime} a d \| I\end{array}$ & $\begin{array}{l}\text { The "star" is given to the students who } \\
\text { can memorise/ perform sunnah acts } \\
a b^{\prime} a d \text { correctly. }\end{array}$ & $\begin{array}{l}\text { Individual guidance in the practice of } \\
\text { sunnah acts } a b^{\prime} a d \text { in fard prayers. }\end{array}$ \\
\hline $\begin{array}{l}\text { Sunnah acts } \\
\text { Hai'ah }\end{array}$ & $\begin{array}{l}\text { The "star" is given to the students who } \\
\text { can respond appropriately during a } \\
\text { revision session. } \\
\text { Motivation improves the readings of } \\
\text { sunnah acts hai'ah, } \\
\text { especially iftitah prayers } \\
\text { and ibrahimiyyah recital. }\end{array}$ & $\begin{array}{l}\text { Individual guidance in the practice of } \\
\text { sunnah acts hai'ah in fard prayers. }\end{array}$ \\
\hline $\begin{array}{l}\text { Activity 13: } \\
\text { PMS }\end{array}$ & $\begin{array}{l}\text { The "star" is given to the students who } \\
\text { can respond appropriately during a } \\
\text { revision session. } \\
\text { The gift card is given to the group who } \\
\text { successfully solved the problem of the }\end{array}$ & $\begin{array}{l}\text { Giving assignments to groups that do not } \\
\text { succeed in resolving the problem of the } \\
\text { acts of voiding fard prayers with the right } \\
\text { rules and reasons. }\end{array}$ \\
\hline
\end{tabular}




\begin{tabular}{|l|l|l|}
\hline & $\begin{array}{l}\text { acts of voiding fard prayers with the right } \\
\text { rules and reasons. }\end{array}$ & \\
$\begin{array}{l}\text { The award card is given to the groups } \\
\text { that show good cooperation. }\end{array}$ & \\
\hline
\end{tabular}

\section{d) Being Engrossed in Fard Prayer Submodule}

The Being Engrossed in Fard Prayer submodule revolves around the concept of engrossed and how to obtain it during fard prayers theoretically and practically.

Table 4: Implementation of Targhib and Tarhib Methods in the Being Engrossed in Fard Prayer submodule

\begin{tabular}{|l|l|l|}
\hline Activities & Implementation of the Targhib Method & Implementation of the Tarhib Method \\
\hline $\begin{array}{c}\text { Being } \\
\text { Engrossed in } \\
\text { Fard Prayer I }\end{array}$ & $\begin{array}{l}\text { Encourage to be engrossed during fard } \\
\text { prayers. }\end{array}$ & Advice, guidance and advice. \\
\hline $\begin{array}{c}\text { Being } \\
\text { Engrossed in } \\
\text { Fard Prayer } \\
\text { II }\end{array}$ & $\begin{array}{l}\text { Encouragement and motivation to strive } \\
\text { for engrossment during fard prayers. }\end{array}$ & Advice, guidance and advice. \\
\hline
\end{tabular}

e) Practice and ljbari in Fard Prayer Submodule

The Practice and ljbari in Fard Prayer offer the assessment and practice of fard prayer as a whole incorporating the qalbi (heart) rule, qauli (word) rule, fikli (action) rule, ab'ad and hai'ah sunnah acts.

Table 5: Implementation of the Targhib and Tarhib Methods in the Practice and ljbari in Fard Prayer's submodule

\begin{tabular}{|c|l|l|}
\hline Activities & Implementation of the Targhib Method & \multicolumn{1}{|c|}{ Implementation of the Tarhib Method } \\
\hline $\begin{array}{c}\text { Fard } \\
\text { Prayer's } \\
\text { practice }\end{array}$ & $\begin{array}{l}\text { The M-Prayer Robot addresses the } \\
\text { students who practised fard prayers } \\
\text { precisely with the name Mumtaz. }\end{array}$ & Individual guidance in fard prayer. \\
\hline $\begin{array}{c}\text { Fard } \\
\text { Ijbayer's }\end{array}$ & Giving words of encouragement. & $\begin{array}{l}\text { Additional assignment on Fard Prayer's } \\
\text { theory. }\end{array}$ \\
\hline $\begin{array}{c}\text { Hayya 'Alal } \\
\text { Falah }\end{array}$ & $\begin{array}{l}\text { The gift is given to the students who have } \\
\text { won a star award in the previous PdPc. }\end{array}$ & Giving advice \\
\hline
\end{tabular}

In addition to the use of the targhib and tarhib method above, a "smiley" sticker is given to students who exhibit a mahmudah nature throughout the learning and facilitation process (PdPc). Generally, the relevant targhib method is implemented in the M-Prayer Robot Module with the recitation of Quranic verses and hadiths related to the advantage of performing fard prayers, stars giving, honors and praise from teachers or the M-Prayer Robots, giving award cards and smiling face stickers. Meanwhile, the use of targhib method is used in the reading of Quranic verses and hadiths 
INTERNATIONAL JOURNAL OF ACADEMIC RESEARCH IN BUSINESS AND SOCIAL SCIENCES

Vol. 10, No. 7, July, 2020, E-ISSN: 2222-6990 @ 2020 HRMARS

related to punishment of neglecting fard prayers, granting of penalty cards, reprimands, advice, guidance and additional assignments during the learning and facilitation process.

\section{Conclusion}

In addition to the use of the targhib and tarhib method above, a "smiley" sticker is given to students who exhibit a mahmudah nature throughout the learning and facilitation process (PdPc). Typically, the appropriate targhib method is implemented in the M-Prayer Robot Module with the recitation of Quranic verses and hadiths related to the advantage of performing fard prayers, stars giving, honours and praise from teachers or the M-Prayer Robots, giving award cards and smiling face stickers. Meanwhile, the use of targhib method is used in the reading of Quranic verses and hadiths related to the punishment of neglecting fard prayers, granting of penalty cards, reprimands, advice, guidance and additional assignments during the learning and facilitation process.

\section{Coresponding Author}

Siti Fauziah Mohd Amin

Faculty of Psychology and Education

Universiti of Malaysia Sabah, 88400, Kota Kinabalu, Sabah, Malaysia

Email: ummuadib1706@gmail.com

\section{References}

Al-Quran al-Karim.

Abdullah, M. H., Sham, F. M., \& Ismail, A. (2018). Pendekatan motivasi dalam dakwah remaja. Journal Hadhari, 10(September 2017), 77-92. Retrieved from http://journalarticle.ukm.my/12103/1/25682-76637-1-SM.pdf.

Alatas, A. R. (2015). Liberalisasi kebijakan pendidikan di Indonesia terhadap metode targhib tarhib. Jurnal TAWAZUN, 8(2), 201-230.

Al-Bukhari, A. A. M. I. (1997). Sahih al-Bukhari. Riyadh: Penerbit Dar al-Salam.

Al-Munziri, A. A. A. Q. (1987). At-targhib wa tarhib minal hadis as-syarif. Beirut: Dar al-Maktabah alHayah.

Anggraini, F. S. (2018). Targhib wa tarhib perspektif al-quran. Jurnal Inovatif, 4(1), 141-165.

Ariyani \& Nursalin. (2016). Method targhib dan tarhib dalam pendidikan menurut hadits Rasulullah SAW. Jurnal Al-Tarbawi, IX(1), 21-38.

Darusalam, G. (2009). Teori dan model pengajaran Pendidikan Islam. Retrieved from https://www.academia.edu/27115808/Teori_dan_Model_Pengajaran_Pendidikan_Islam

Darusalam, G., \& Husin, S. (2018). Metodologi penyelidikan dalam pendidikan. Kuala Lumpur: Penerbit Universiti Malaya.

Fathoni, M. (2012). Implementasi pendidikan karakter melalui metode targhib dan tarhib bagi santri di Pondok Pesantren Tahfidhul Qur'an Sunan Giri Surabaya. Institut Agama Islam Negeri Sunan Ampel Surabaya.

Hussin, S. A. S. (2005). Pendekatan targhib dan tarhib dalam penyampaian dakwah. Jurnal Usuluddin, 21, 117-138.

Ismawati. (2018). Pola penerapan metode targhib wa tarhib pada pembelajaran tahsin tahfidz di SMPIT Bina Insan Kota Metro. At-Tajdid, 02(02), 170-187. 
INTERNATIONAL JOURNAL OF ACADEMIC RESEARCH IN BUSINESS AND SOCIAL SCIENCES

Vol. 10, No. 7, July, 2020, E-ISSN: 2222-6990 @ 2020 HRMARS

Jasmi, K. A., \& Tamuri, A. H. (2013). Pendidikan Islam kaedah pengajaran dan pembelajaran. Johor Bahru: Penerbit UTM Press.

Kurniawan, B. (2016). Konsep targhib dan tarhib dalam prespektif Teori Belajar Behavioristik. AnNidzam, 03(01), 103-116.

Ma'rufin. (2015). Metode targhib dan tarhib (reward dan punishment) dalam Pendidikan Islam. Jurnal Risaalah, 1(1), 67-77.

Mustapha, N. A., Sham, F. M., \& Mokhtar, A. I. (2019). Pendekatan dakwah targhib dan tarhib dalam membina adab remaja. Jurnal Hadhari, 11(2), 267-290.

Prahara, E. Y. (2015). Metode targhib wa tarhib dalam Pendidikan Islam. Cendikiawan, (13), 157169.

Tamuri, A. H., \& Yusoff, N. M. R N. (2010). Kaedah pengajaran dan pembelajaran Pendidikan Islam (1st ed.). Bangi: Penerbit Universiti Kebangsaan Malaysia.

Tamuri, A. H., \& Ajuhary, M. K. A. (2010). Amalan pengajaran guru Pendidikan Islam berkesan berteraskan konsep mu'allim. Journal of Islamic and Arabic Education, 2(1), 43-56.

Ramli, M. (2015). Media pembelajaran dalam perspektif al-quran dan al-hadis. Ittihad Jurnal Kopertais Wilayah XI Kalimantan, 13(23), 130-154.

Salamattang. (2011). Aspek-aspek pendidikan dalam salat. Lentera Pendidikan, 14(1), 68-87.

Salleh, A. M. (2011). Kurikulum, metodologi dan pedagogi Pengajian Islam (1st ed.). Shah Alam: Oxford Fajar Sdn. Bhd.

Sarbini, D. A. (2015). Metode pengajaran dalam Pendidikan Agama Islam. Jurnal Al-Fatih, 92-93.

Setiawan, A., \& Kurniawananto, E. (2016). Metode Pendidikan Islam masa kini dalam keluarga perspektif Abdullah Nashih Ulwan. EDUCASIA, 1(2), 137-154.

Sudarto. (n.d.). Implementasi metode targhib dan tarhib dalam pembelajaran akidah akhlak peserta didik Mts Hidayatus Syubban Karangroto Genuk Semarang. Jurnal Waspada, 36-54. 